\title{
CORPORATE FREEZEOUTS AND THE PROTECTION OF MINORITY SHAREHOLDERS IN ALBERTA COMPANIES
}

\author{
H. SHANDLING*
}

The Alberta Interpretation Act ${ }^{1}$ vests in the majority of members of a corporation the power to bind the others by their acts. That this power is not unfettered has been established in a series of decisions indicating that the powers of the majority should be exercised "subject to those general principles of law and equity which are applicable to all powers conferred on majorities." 2 The extent to which general principles of law and equity apply is contentious, and it has been found necessary in the Alberta Companies Act ${ }^{2 a}$ to supplement the dubious protection so afforded minorities, by specific curbs on majority action.

The powers of the majority are not confined to a dominance in corporate decision making. Their majority powers enable them to use their control to eliminate effectively the minority from the corporate enterprise, to reduce their voting power to relative insignificance, to deprive them in whole or in part of their claim to corporate assets and to deprive them of income or other corporate advantages. The generic term "corporate freezeout," used in the United States to embrace these actions, is apposite in describing the plight of shareholders left out in the cold. ${ }^{\mathrm{a}}$

\section{FREEZEOUT TECHNIQUES}

It is proposed to examine the freezeout techniques and the protection available to minority interests in Alberta companies. Kerr writing of fraud describes it as "infinite and [will] always attempt to evade whatever is done for its suppression; to prune it back on one side is but to give it a stimulus to branch out with fresh vigour in another direction." A like vitality infuses freezeout schemes which find fertile ground in legislative amendments. ${ }^{5}$ To attempt to list the devices that could be used would be to catalogue the reaches of the imagination. What follows is not a comprehensive list but is intended by way of illustration only.

1. Voting of excessive directors' remuneration effectively diverts profits from the shareholders as a whole to the majority. ${ }^{\circ}$ This technique is especially effective, since the directors are usually the major shareholders or their nominees. The employment of

* H. Shandling of the Alberta Bar (Edmonton) and Attorney of the Supreme Court of South Africa.

1 (Alta.) 1958, c. 32, s. 13 which provides: Words in an enactment establishing a corporation

(a) .

(b) vest in a majority of the members of the corporation the power to bind the others by thelr acts.

See also the Alberta Companies Act, R.S.A. 1955, c. 53, s. 127 (1), which confers, subject to the articles, one vote for each share.

2 Allen v. Gold Reefs of West Africa, [1900] 1 Ch. 656 (C.A.).

2a Ante, n. 1.

8 This definition is adopted from ONeal, Close Corporations, \$8.07, p. 105 (1958).

4 Kerr, Fraud and Mistake 300 (7th ed. 1952).

5 The statutory powers given a majority to compel the minority to agree to structural The statutory powers given a majority to compel the minority to agree to structural
changes and compromises have incidentally given the majority a further means of
freezing out the minority. freezing out the minority

- Nolan v. Parsons, [1942] 3 D.L.R. 190 (Ont. C.A.), and Houston v. Victoria Machinery Depot Ltd., [1924] 2 D.L.R. 657 (S.C. B.C.) illustrate the approach of the Courts to remuneration of directors, where the minority have complained. 
major shareholders, either unnecessarily or at excessive remuneration, has a similar freezeout effect.

2. The majority may have interests in outside corporations. A contract may be entered into with the outside corporation, which while disadvantageous to the company, may benefit the other party. The majority thus obtain an advantage at the expense of the minority. Pavlides v. Jensen ${ }^{7}$ illustrates this situation. The Tunnel Company owned a mine in Cyprus, and the directors agreed to sell the mine to a company which controlled the major shareholding in Tunnel. Pavlides, a minority shareholder tried to set the sale aside, alleging that the mine had been sold at a fraction of its value. The Court refused to intervene, holding that it was for the shareholders in general meeting and not an individual shareholder to take action. The shareholders in general meeting were hardly likely to complain, so the minority were effectively deprived of their interests in the mine. Professor Gower in discussing the decision ${ }^{8}$ says that its practical effect is to confer on the majority a license to give away all the company assets. In Central Gas Utilities Ltd. et al v. Canadian Western Natural Gas Co., ${ }^{9}$ a holding company had acquired a gas franchise owned by its subsidiary. Milvain, J. indicated that it was quite proper for shareholders to vote in favour of a transaction even if it were in advancement of their own interests (in this case the sale of a franchise to another company in which they were interested).

3. Voting against the declaration of dividends renders minority shares less valuable and makes their retention less attractive. ${ }^{10}$

4. The allotment of further shares other than pro rata existing shares can dilute minority interests. While the directors (occupying as they do a fiduciary position) could not do so, there is no prohibition on shareholders so doing. In fact, Articles 27 and 28 of Table $A^{10 a}$ sanction this procedure. All shares are to be offered to such persons as a special resolution may direct.

A freezeout may also be achieved in a manner less blatantly unfair. A large increase in capital can be voted, to be available pro rata existing shareholding when it is known that the minority is not able to take advantage of the offer. This preserves the shadow but not the substance of fair dealing.

5. In line with the aforegoing, calls on shares may be made when the capital is not required, primarily to embarrass the minority.

6. The cash resources of companies are fruitful pickings for those who wish to garner its abundance for themselves. The facade

7 [1956] 2 All F.R. 518 (Ch.).

8 Comment (1956), 19 M.L.R. 538, where he cites the decision as an illustration of the unhappy working of the rule in Foss v. Harbottle (see post), which he suggests should be decently interred.

9 (1964), 49 W.W.R. 513 (S.C. Alta.). Although the resolution was found in fact to be reasonably in the interests of the company, the judgment suggests that even had this not been so, the proceedings would not have been faulted. This judgment has been upheld by the Supreme Court of Canada in a still unreported decision.

10 In Burland v. Earle, [1902] A.C. 83 (P.C.. Ont.), the Board upheld a decision that the company should not be compelled to declare a dividend.

10a Alberta Companies Act, ante, n. 1 . 
of legality is preserved by casting the transaction in the form of a loan. In a recent report on company operations a stock exchange executive remarked, "Once funds have been obtained by public subscription there is very little to prevent the syphoning off of those funds for the profit of the insiders. This practice has become far more prevalent than the public realizes." ${ }_{11}$ Restrictions are found in section 14 of the Act, but these restrictions apply only to public companies.

7. Loans can be repaid preferentially to majority shareholders.

8. The power to liquidate the company can be an effective weapon in the freezeout armoury. The assets can then be acquired, either directly, or through a corporation controlled by the majority. This was recognized by the Cohen commission, reviewing the Companies Act in the United Kingdom. The commission pointed out that "In many cases however, the winding-up of a company will not benefit the minority shareholders, since the break-up value of the assets may be small, or the only available purchaser may be that very majority whose oppression has driven the minority to seek redress." 12 A de facto liquidation can be achieved where the company, at the behest of the majority, ceases to trade or passes up trading opportunities in favour of other enterprises controlled by the majority..$^{13}$

9. Shareholders take up membership on the basis of the articles of association; creating a relationship described as analogous to a contract between the company and its members, ${ }^{14}$ with the articles constituting terms incorporated by reference into the contract. ${ }^{15}$ The analogy is faulty, for a relationship where one of the parties can change the terms hardly resembles contract. Such is the power of the company as dictated by the majority. The articles are not immutable. Section 52 of the Act allows alteration by special resolution. Far reaching changes have been approved, for the courts will interfere only in cases characterized as "fraudulent" or "oppressive".15a In Greenhalgh v. Arderne Cinemas $L t d .{ }^{16}$ two groups of shareholders were at loggerheads. The articles contained the usual first refusal rights on the sale of shares. The majority group had received an attractive offer for their shares (which included compensation for loss of office). To circumvent the articles a resolution was approved eliminating the first-refusal rights, and this was followed by an offer for the total shareholding. Evershed, M. R. observed that no shareholder had the right to assume that the articles would remain

11 Report of the Committee on the Draft Uniform Companies Act, to the Canadian Bar Association 103 (1963 Annual Meeting).

12 Report of the Committee on Conpany Law Amendment, Para. 60 (Cmd. 6659. 1945).

13 Scottish Co-operative Wholesale Society Ltd. v. Meyer, [1958] 3 W.L.R. 404 (H.L.), illustrates this situation. The Society had, with ieyer, formed a company to engage in the rayon trade. The new company bought cloth for processing from the Soclety which held the majority of the shares. The Society then ceased to supply cloth, bringing the operations of the new company to a standstill. Because of the amendment to the United Kingdom Act (11 \& 12 Geo. $6 . \mathrm{c} .38 \mathrm{~s}$. 210), relief was afforded to the minority shareholder Meyer. This section is not found in the Alberta Act. This case and section 210 are discussed in a note by A. L. Goodhart in (1959), 75 L.Q.R. 38.

14 Imperial Hydropathic Co., Blackpool v. Hampson (1882), 23 Ch. D. 1 (C.A.)

15 See Welton v. Saffery [1897] A.C. 315 per Lord Herschell where he said: "It is quite

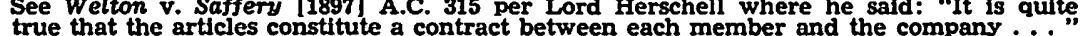
16 a See post.

16 [1950] 2 All E.R. 1120 (C.A.). 
unchanged, and refused to upset the resolution. Amendments challenged and upheld include: provision for a lien on shares fully paid up for moneys which thereafter became due to the company; provision for the removal of a director not otherwise compelled to vacate his office, ${ }^{17}$ and resolutions to compel shareholders with interests in rival concerns to sell their shares. ${ }^{18}$ Class rights attaching to shares are more firmly entrenched, but as will be seen, these too can be modified.

10. The direction of the enterprise is usually vested in the directors, and it can be expected that they will be the major shareholders, or their nominees. Because of their constant contact with company affairs, they will often be entrusted, if only by default, with the exercise of decisions-making powers properly the province of the general body. It is through the directors that information is made available, and to deny the information or to provide incomplete or other misleading information will result in a mere rubber-stamping of directors' wishes. The power to nominate a directorate is "manifestly capable of great abuse and may involve in the misuse of it evil consequences to multitudes of people who have little capacity to guard themselves."10

11. At common law a corporation could not undertake a merger or other structural change without the unanimous consent of the members. The Act introduces provisions for amalgamation, schemes of compromise and reconstruction. A recalcitrant minority is prevented from impeding the interests of the company. These provisions have effected a further shift in the corporate balance of power, transferring to the majority a control which would otherwise have been lacking. It has provided yet another freezeout method, for not only the obdurate, but all minorities become subject to the majority wish.

The sections in the Act are:

(i) section 48 and 78, which provide for reorganization of capital and alteration of class rights by special resolution and Court sanction;

(ii) section 138, which provides that where an offer to acquire the shareholding is accepted by $90 \%$ of members, the remaining $10 \%$ are compelled to sell unless the court on their application orders otherwise;

(iii) section 139, which provides that where a compromise between the company and its members or creditors is accepted by $75 \%$ of those voting at a meeting specially called, it can be declared by the court to be binding on all members;

(iv) section 140, which deals with compromises resulting in mergers or amalgamations, and

(v) section 231, which allows a company in liquidation, or about to be placed in voluntary liquidation, to sell its assets for

17 Allen v. Gold Reefs of West Africa Ltd., ante, n. 2. Shuttleworth v. Cox Bros. \& Co. (Maidenhead), [1927] 2 K. B. 9 (C.A.) (removal of directors).

18 Sidebottom V. Kershaw, Leese \& Co., 11920$] 1$ Ch. 154 (C.A.) (sale of shares)

10 Per Lord O'Hagaen in Erlanger v. New Sombrero Phosphate Co. (1873), 3 App. Cas. 1218 (H.L., cited in Proprietary Mines Ltd., v. McKay [1938], O.R. 514 (S.C. Ont.). 
shares to be distributed among the members, while dissentients can have their interests bought out at a valuation. ${ }^{20}$

The Bugle case ${ }^{21}$ illustrates an abuse of the powers conferred by these sections. Two shareholders held $90 \%$ of the shares and wished to acquire the $10 \%$ held by the third. To effect their purpose, since he was unwilling to sell, they formed a company which made an offer to buy all the shares in Bugle. A 90\% acceptance was of course obtained, and it was sought under the equivalent of section 138 to compel the third shareholder to sell. ${ }^{22}$

The advantages attached to being a controlling shareholder are recognized in share valuations. The Estate Tax Act, ${ }^{23}$ for example, draws a distinction between the valuation of minority interests and controlling interests. ${ }^{24}$

\section{PROTECTION AVAILABLE TO MINORITY SHAREHOLDERS}

That minority shareholders need special protection has long been recognized. A discordant note was struck by the approach of the Ontario Commercial Law sub-section of the Canadian Bar Association. Dealing with a proposed protection in the Draft Uniform Companies Act, they remarked, "Section $\mathbf{1 1 5}$ might be said to show an undue concern for the position of the minority shareholder who is after all in that position of his own volition." would suggest that no protection at all is necessary for the minority, since they have voluntarily assumed that position. This laissez faire posture has fortunately been left behind in most legislation. Facing the practicalities of commercial conditions, the tendency has been to extend the protection of minorities.

\section{Statutory Protection}

Certain corporate decisions are considered to be of such moment that a simple majority will not suffice. In these cases a special resolution requiring a three-quarter majority is necessary. ${ }^{20}$ Sometimes a special resolution alone is not enough and an extraordinary resolution is required. The latter is a resolution passed with the same majority, but where in addition, notice has been given of the intention to propose the resolution. ${ }^{27}$ Recognizing the inadequacy of these protections the Act provides

20 For a comprehensive survey of amalgamation procedures avallable under the Alberta Act, see G. H. Allen, Mergers and Amalgamations (1964), 3 Alta. L. Rev. 463.

21 Re Bugle Press Ltd., [1960] 1 All E.R. 768. (Ch.).

22 The scheme failed because the Court held that the $90 \%$ had to represent a disinterested majority. This argument commended itself to the Supreme Court of Canada in Esso Standard (Inter-America Inc.) v. J. W. Enterprises and Morristoe, [1963] S.C.R. 144 (see post).

23 (Can.) 1958, c. 29

24 And see Dymond's Death Duties 380 (12th ed. 1955)

25 Report of the Committee on the Draft Uniform Companies Act to the Canadian Bar Association, ante, $\mathrm{n} .11$ at 116.

26 For definition of a special resolution-see section 2 (ff). Special resolutions where minority interests may be affected include:

alteration of articles, section 52;

change of name, section 43;

change of name, section 43;

convolidation, etc., of share capital, section 47 ;

consolidation, etc., of share capital, section 47;

paymetion of capital by return of accumulated profits, section 114:

reduction of capital by return of accumulated profits, section

voluntary winding-up, section 219

sale of assets on liquidation, section 231.

27 For definition of an extraordinary resolution, see section $2(q)$. These include alterations of share capital, section 46: compromise by liquidator, section 208 : approving acts of llquidator, section 229. 
that certain resolutions must in addition have the sanction of the Court, or directs the court to intervene where the dissidents show cause. ${ }^{28}$ (This is understandable for all that the special and extraordinary resolutions do as far as minority protection is concerned is to ensure that if there is to be a freezeout it shall be a freezeout by more than a bare majority. The rationale behind the increased majority is probably not to provide additional protection but rather to ensure that in view of the gravity of the decision it be reached by a consensus closer to unanimity?). The Act does not set out the conditions under which the courts should give their sanction. As was pointed out by Porter, J. A. in Fogler v. Norcan Oils, ${ }^{29}$ in referring to sanction in amalgamation schemes: "the statute itself gives no guidance and imposes no limits as regards the grounds on which the judicial discretion is to be exercised."20a The following are some of the principles on which courts have acted when required to approve a vote:

1. The Court must be satisfied that the statutory procedure has been followed. Where a member's property is being taken from him, for example under a take-over in terms of section 138 , the court must be satisfied that the act has been strictly complied with. ${ }^{30}$ Once the majority have discharged this onus, however, it has been held that the dissentient is faced "with the very difficult task of discharging an onus which is undoubtedly a heavy one-of showing that he, being the only man in the regiment out of step, is the only man whose views ought to prevail." ${ }^{11}$

2. It must be clear that an intelligent and honest man would vote for it $^{32}$ and sensible business men would approve. ${ }^{33}$

3. The court must examine the scheme and see if it is fair and reasonable. ${ }^{84}$

4. The court must scrupulously regard the rights of minority shareholders. ${ }^{35}$ Thus, in Re Provincial Apartments Ltd., ${ }^{36}$ the court refused to sanction a scheme depriving preference shareholders of certain rights, holding that it would not allow the common shareholders to "feast on the rights" of the preference shareholders.

5. The shareholders must have been given accurate and adequate information so as to arrive at an informed decision, ${ }^{37}$ and the

28 Amalgamation and compromise schemes (ante, n. 20) alteration of class rights, enlargement of objects and reduction of capital, require this sanction. In section 138 take-

29 (1964), 47 W.W.R. 257 (Alta. C.A.). Reversed on further appeal, but on other grounds. Reported sub. nom., Norcan v. Gridoil, 49 W.W.R. 321.

29 Id. at 263.

30 In Re Brazilian Traction Light, etc., Co. Ltd., [1947] O.R. 791; Fogler v. Norcan Oils, ibid; In Re Alabama, New Orleans, Texas and Pacific Ry., (1891] 1 Ch. 213 (C.A.); Re Dairy Corporation of Canada Ltd., (1934] O.R. 436;

Rathie v. Montreal Trust Co., [1953]'2 S.C.R. 304

81 Per Valsey, J. in Re Sussex Brick Co. Ltd., [1960] 1 All E.R. 772 (Ch.). He also says that the scheme must be unfair to "the meanest intelligence." This is cold comfort for a minority.

32 In Re Brazilian Traction, etc., ante, n. 30

83 Re Western Canada Flour Mill, [1945] 1 D.L.R. 589 (Ont. H.C.)

Re National Grocers Ltd., [1938] O.R. 123.

4 Re Langleys Ltd., [1938]'O.R. 123;

Re Dorman Long \& Co. Ltd., [1934] Ch. 635.

5 Re Langleys Ltd., ante, $\mathbf{n}$. 34).

Re National Grocers Ltd., ante, n. 33

36 [1936] 3 W.W.R. 327 (Sask. K.B.).

37 Fogler v. Norcan Oils, ante, $\mathbf{n}$. 29; Rathie v. Montreal Trust Co., ante, n. 31 ; In re st. Lawrence Corporation \& Mayr, [1948] 2 D.L.R. 107 (Que. S.C.); but see In Te Evertite Locknuts, [1945] Ch. 220, where inadequate information was considered insufficient to persuade the court to intervene on behalf of the minority in a section 138 type of scheme. 
directors must honestly put forward to the best of their skill and ability a fair picture of the company's position. ${ }^{38}$

6. At the same time the court will be guided by the majority decision, an approach which effectively casts an onus on the minority to show why the scheme should not be approved, rather than on the majority to justify it. This attitude is exemplifeid by observations of the following type: the court will pay the greatest attention to what business people who are concerned with the transaction decide; ${ }^{30}$ what is fair from a business standpoint can generally best be judged by the opinion of businessmen rather than judges; ${ }^{* 0}$ shareholders acting honestly are better judges of the advantage to the company than the courts; ${ }^{41}$ the court must be guided by the voice of reasonable businessmen who understand the nature of business, ${ }^{42}$ and, where a very large majority desire a certain procedure the court should give effect to it. ${ }^{43}$ This reluctance to interfere is perhaps an abdication of the duty specifically imposed on the courts by the legislature. By relying on the majority decision the freezeout protection envisaged is nullified. As will be illustrated by the rule in Foss v. Harbottle, ${ }^{44}$ the courts are reluctant to sit in judgment on the decisions of shareholders; but here they have been specifically charged so to do. There is no mystique in the management of companies that is beyond the understanding of the courts. It displays an unjustified modesty to suggest that shareholders, by the mere act of acquiring a share, are in a better position to decide on the efficacy of a scheme than a judge. If one takes account of the realities of a corporate decision, it will often be revealed as a mere rubber-stamping of a decision placed before a meeting rather than the considered and informed opinion of businessmen-shareholders. ${ }^{\text {ta }}$

7. The courts have considered the situation where a member may hold shares in more than one class. He may vote to surrender privileges in one class because he will get a greater benefit as a member of another class. Such a shareholder will not be considered as truly disinterested, and the courts will take this into account in deciding whether to give their approval. In deciding whether the necessary $90 \%$ acceptance of an offer has been obtained in section 138 procedures, the courts have taken into account analogous conflicts of interest. In the Esso case, ${ }^{47}$ Esso Petroleum had made an offer to purchase all the shares in International Petroleum Co. Ltd. A 90\% acceptance was obtained, but a substantial part of this $90 \%$ consisted of shares owned by a subsidiary of the offeror Esso, which would obviously be in favour of the scheme. The Supreme Court of Canada held that there had

38 Re I.C.I. Ltd., [1936] Ch. 587 (C.A.). Clted with approval in Fogler v. Norcan Oils, ante, n. 29

s9 Re Bugle Press, ante, n. 21.

40 Re Dorman Long \& Co. Ltd., ante, n. 34

41 Carruth v. Imperial Chemical Industries, [1937] A.C. 707 (H.L.).

42 Sidebottom v. Kershaw, Lesse \& Co., ante, n. 18

43 Re Bailey Cobalt Mines Ltd. (1920)' 47 O.L.R. is.

44 (1843), 2 Hare 461, 67 E.R. 189. See post. interesting account of the timidity of shareholders.

45 Ante, n. 22, and see also Re Canadian Breweries Ltd., [1964] C.S. 600 (Que.), which indicates that the $90 \%$ cannot be obtained plecemeal over a period but must result from a single offer. 
not been a disinterested $90 \%$ and agreed that the minority could not be compelled to accept the offer.

\section{Fraud on the Minority}

The above are instances of court intervention in terms of specific legislative direction to examine the votes of shareholders. Even in the absence of such direction the courts will examine votes not falling in the categories listed in the Act. The cases where the courts will do so are generally described as instances of fraud or oppression of minorities. The right so exercised can be an important safeguard. Unfortunately the circumstances under which a court will interfere have not been set out with any degree of precision. Thus, a shareholder has been described as having a duty to cast his vote in a fiduciary fashion, in the interests of the company rather than himself, ${ }^{46}$ and by contrast as having the right to vote as he sees fit even though it be to further a transaction to his own advantage.47 Can a shareholder then vote as he pleases? All authorities agree that the majority cannot act oppressively or fraudulently. But the range of conceptions of the duty of the majority towards the minority is so great that the words "oppressively" or "fraudulently" in themselves provide no answer. "Fraudulent" can be used either in the sense of deceit, or in the sense of equitable fraud, so that any act whereby undue or unconscionable advantage is taken of another, or in the latter sense, where there is a lapse from the high standards of conscientiousness expected from a party occupying a fiduciary relationship towards another, can be construed as fraud. In this latter sense the idea of a free vote is negatived. In the former it is not. Buckley describes oppression as "a visible departure from fair dealing." 48 This is really begging the question, for what is fair dealing ?9 $^{49}$

\section{(a) The Cases}

It is proposed to examine the decisions to see if some greater precision can be given to the words fraudulent and oppressive, so that we have a principle "which with a reasonable measure of probability may be predicted as the basis for judgment in pending or future controversies." Menier v. Hooper's Telegraph Works (Limited), ${ }^{51}$ generally regarded as the locus classicus in regard to minority rights, is a useful starting point. The effect of a series of resolutions was to dispose of the assets of the company in such a way that they came into the possession of the majority, the minority being effectively excluded. It was said that, "the majority has divided the assets of the company, more or less, between themselves, to the exclusion of the minority ... it would be a shocking thing if that could be done, because if so, the majority might divide among themselves the whole assets of the company, and pass a resolution that everything must be given to them, and that the minority should have nothing to do with it."s1a Following this decision, Lindley, M. R. in Allen v. Gold Reefs of West Africa, ${ }^{\mathrm{s} 2}$ considered the power of the majority and

46 Carr v. B.C. Nickel Mines Ltd. (no. 2), [1937] 3 W.W.R. 61 (S.C. B.C.).

47 Centrai Gas Utilities Ltd. v. Canadian Western Natural Gas Co., ante, n. 9.

48 Buckley, Companies Act 423 (13th ed. 1957).

49 See the remarks of Astbury, J. in Brown v. British Abrasive Wheel Co., [1919] 1 Ch. 290 , 295, where he described oppression as a departure from "ordinary principles of justice."

50 Cardozo, The Growth of the Law 44 (Yale University Press 1924).

51 [1874] L.R. 9 Ch. App. 350.

$\checkmark 2$ Ante, n. 2 
said that it "must . . . be exercised subject to those general principles of law and equity which are applicable to all powers conferred on majorities and enabling them to bind minorities. It must be exercised, not only in the manner required by law, but also bona fide for the benefit of the company as a whole, and it must not be exceeded." proach reached its highwater mark in the analysis of Lindley, M. R.'s remarks in Greenhalgh v. Arderne Cinemas, ${ }^{53}$ where Evershed, M. R. observed that the words, "bona fide for the benefit of the company as a whole," meant, "the corporators as a general body," that is, the individual shareholders rather than the company as a separate entity. In Shuttleworth v. Cox Brothers \& Co. (Maidenhead), ${ }^{54}$ Bankes, L. J. said that the Court should consider a minority complaint in the same way as it would consider a jury verdict; if the decision was such that no reasonable men could consider it for the benefit of the company, it would be upset. The British Columbia Court of Appeal considered the matter in Royal Trust v. Norrie. ${ }^{3 s}$ The deceased had held the majority of the shares in a private company, the articles of association containing first-refusal provisions in favour of shareholders. In his will the deceased had directed that on his death his shares were to be transferred to a designated party. To avoid the requirements of the articles, which would have required the shares to be offered first to the remaining shareholders, the executors, to whom the shares were in the interim transferred, secured passage of a resolution deleting the provisions. The court, while accepting that there was a duty on shareholders to use their votes in the interest of the company, found that in the instant case this duty had been observed. All the decisions had not pointed the same way and some years earlier Fisher, J. in Carr v. British Columbia Nickel Mines, ${ }^{56}$ had reviewed the conflicting decisions and concluded that a majority could not abuse the right of the minority to have decisions determined by shareholders acting in good faith for the benefit of the company. He indicated that if the result of a resolution is to divide the assets unfairly, a court will conclude that the vote was not bona fide. If the evidence does not go so far, the court will not interfere, unless the act is such that reasonable men would not consider it to be for the company benefit. Nolan v. Parsons $^{57}$ was an Ontario case where the directors had voted heavy fees to themselves and had obtained the approval of the majority of the shareholders, largely themselves, at a general meeting. The vote was upset, being described as fraudulent in the sense that an undue or unconscientious advantage had been taken of the minority.

Kerr summarises the above viewpoint by saying "the majority acting bona fide can determine whether the resolution is for the benefit of the company." which does not subscribe to the fiduciary approach. In Pender v. Lushington, ${ }^{\text {so }}$ Jessel, M. R. said, "There is, if I may say so, no obligation on a shareholder of a company to give his vote merely with a view to what other persons may consider the interests of the company at large. He

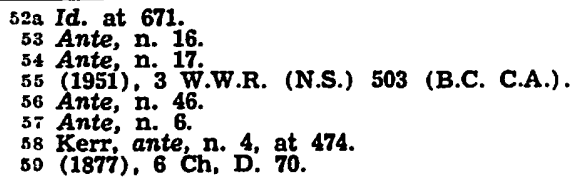


has a right, if he thinks fit, to give his vote from motives or promptings of what he considers his own individual interest." (on appeal to the Privy Council from Ontario), there was an application to compel the company to distribute its profits. The board indicated that it would not interfere with a shareholder's right to vote as his particular interests dictated. In North-West Transportation Co. v. Beatty ${ }^{61}$ (on appeal from Ontario), the Privy Council again considered the matter. Here it refused to recommend that a sale of assets to a major shareholder be set aside. Sir Richard Bagalley said "Great confusion would be introduced ... [if shareholders], voting in that character . . . stood in some fiduciary relation to the company." case, ${ }^{62}$ Milvain, J. declared that "a shareholder can vote his shares as he sees fit, even though it be to further a transaction to his own advantage." $62 \mathrm{a}$

The numerous decisions where a shareholder has been compelled to vote in accordance with an agreement to vote his shares in a particular way are in line with the latter attitude. Such agreements have been supported by injunction to restrain a contrary vote. ${ }^{63}$ This is hardly consistent with a duty to vote as dictated by the interests of the company.

\section{(b) Nature of a Share}

The antinomies in the theories may perhaps be resolved by an examination of the nature of a share. There are certain fundamental characteristics and rights attaching to membership. A share is a right to receive a proportion of the profits, and on winding up, of the assets of the company. The purpose of entering a company is, in common with the other members, to make a profit (see for example the Alberta Companies Act, which talks of "an association to carry on business which has for its object the acquisition of gain") ${ }^{64}$ When a vote does not observe these fundamental purposes and rights it can be described as oppressive. Decisions which transfer assets from the company to the majority have been upset. ${ }^{o s} \mathrm{~A}$ vote to deprive the minority of their interests by compelling them to sell their shares has similarly been defeated. ${ }^{\circ}$ A deprivation of the minority of their share of profits has resulted in court interference. ${ }^{67}$

60 Id. at 75 .

co Ante, n. 10.

61 (1887), L.R. 12 App. Cas. 589.

61 Id. at 600 .

62 Ante, n. 9.

$62 \mathrm{Id}$. at 525.

63 Motherwell v. Schoof, [1949] 2 W.W.R. 529 (S.C. Alta.); Greenwell v. Porter, [1902) 1 Ch. 530.

64 Section 8(1).

65 Menier v. Hooper's Telegraph Works, ante, n. 51, where assets were transferred to the majority to the exclusion of the minority;

Griffith v. Paget (1877), $5 \mathrm{Ch}$. D. 894, where a company was wound up and all the assets transferred to a new company in which the minority were granted a smaller interest than before; and

Cook v. Deekes, [19i6] 1 A.C. 554 (P.C. Ont.), where the directors of a company took up a contract for themselves instead of for the company, and then had the shareholders pass a resolution stating that the company had no interest in the contract. The contract in equity belonged to the company as the directors were its trustees and the effect of the resolution was to give them a company asset.

68 Brown v. British Abrasive Wheel Co., Ante, n. 49.

67 Nolan v. Parsons, ante, n. 6: excessive directors' fees were held to be a deprivation of the profits which should have been avallable to all shareholders. See also Fuller v. Bruce, [1935] 3 D.L.R. 256 (S.C. N.S.). 


\section{(c) Actual Fraud}

Where there has been actual as opposed to constructive fraud the courts will give relief as in all cases of fraud. No principles of specific application to companies apply. Thus in Attwool v. Merryweather, ${ }^{68}$ the majority voted to purchase a mine at an inflated value, because they were to receive a secret benefit. (If the transaction had been open it is suggested that it would have been set aside as oppressive, because it would have resulted in an unfair diversion of company profits to the majority, and because it would not have been in furtherance of the acquisition of gain for the company). Resolutions obtained by a trick would also be set aside. ${ }^{30}$

Resolutions which offend in one respect may be upheld because they are justified in another. In Nolan v. Parsons, ${ }^{70}$ directors' fees were disallowed because they were a sham to deprive the minority of their share of the profits. In Houston v. Victoria Machinery Depot Ltd., ${ }^{11}$ these fees were allowed because they were a reasonable part of the cost of earning a profit. The courts have upheld changes in the articles which deprived members of existing rights, and have upheld a refusal to declare dividends. In both cases these resolutions could be justified as part of the overall scheme of making a profit for the company.

(d) Onus

The onus is always on the minority to prove that a resolution is fraudulent or oppressive, since they will be taking the offensive. If resolutions can be construed as being in pursuit of the object of gain, the court will, where there is doubt, accept this construction. ${ }^{72}$ The actions of the majority can afford evidence of a freezeout scheme. If there has been a persistent attempt by the majority to buy out the minority, and this is followed by a refusal to vote dividends, it is suggested that the majority action would be suspect. Evidence of past hostility could negative an attempt to justify the majority action. Other indicia of impropriety include, a disproportionate benefit to the majority, or misleading information. It is suggested that cases where winding-up has been decreed because of oppression of minorities, afford indications of the type of evidence which would show that a resolution was oppressive. ${ }^{78}$

\section{(e) Class Votes}

A distinction has been drawn between an ordinary vote and a vote as a member of a class. In British American Nickel Corporation v. $O^{\prime} B r i e n^{74}$ (on appeal to the Privy Council from Ontario), the issue con-

68 (1868), L.R. 5 Eq. 464.

69 Baillie v. Oriental Telephone Co., [1915] 1 Ch. 503 (C.A.).

70 Ante, n. 6 .

71 [1924] 2 D.L.R. 657 (S.C. B.C.).

72 Cases where the Courts have refused to interfere include:

Burland $\mathrm{v}$. Earle, ante, $\mathrm{n}$. 10, where dividends were not being declared;

In re Pacific Coast Coal Mines Ltd. and Hodges, [1926] 3 W.W.R. 378 (B.C. C.A.), where

the majority decided to liquidate the enterprise:

Dominion Cotton Mills Co. Ltd. v. Amyot, 11912) A.C. 546, (P.C. Que.), where the Privy

Council refused to recommend a decision to enter into a lease be set aside;

North-West Transportation Co. v. Beatty, ante, n. 61; and

Normandy v. Ind. Coope \& Co., [1908] 1 Ch. 84: benefits voted to directors.

is Loch v. John Blackwood, Ltd., [1924] A.C. 783 (P.C.): winding-up was granted where

it was found that the minority had been unfairly treated-the principal shareholders refused to produce accounts or to pay divldends. It has been held that in small private companies, facts which would justify the dissolution of a partnership may be grounds for a winding-up order: Re Davis and Collert Ltd., [1935] Ch.693.

74 [1927) A.C. 369 . 
cerned a debenture trust deed which could be altered by a majority vote. A resolution to that effect was passed, some of those supporting it having received an additional inducement. Viscount Haldane said of the voting, which had been challenged by the minority, "No doubt he was entitled in giving his vote to consider his own interests. But as that vote had come to him as a member of a class he was bound to exercise it with the interests of the class itself kept in view as dominant. It may be that ... he and those with whom he was negotiating considered the scheme the best way out of the difficulties with which the corporation was beset. But they had something else to consider in the first place. Their duty was to look to the difficulties of the bondholders as a class ..."7s Those who understandably find it difficult to appreciate why a distinction should be drawn between a vote given as a member of a class of shareholders, and a vote as a member of the general body of shareholders may take solace in the observation in the speech that the distinction is a "fine one".

\section{(f) Rule in Foss v. Harbottle}

The rule in Foss v. Harbottle $e^{76}$ should be referred to. Stated broadly, where a wrong is done to a company, it is for the company, expressing its wishes by majority decision, to take action. If the majority have voted, the company has spoken, and it is not for individual members to object that a wrong has been done the company. Thus in the Pavlides case, ${ }^{77}$ the court would not intervene where minority shareholders thought that the company was receiving an unfair price for an asset. If something has been done irregularly, which the majority can do regularly, or if something has been done illegally which can be done legally, there is no point in litigation, for the majority can always call a meeting to approve their action. There are certain qualifications to the rule. ${ }^{i 8}$

(i) where the vote has been oppressive or fraudulent as set out above. If this were not so, the minority could never be heard to complain. In Ingre v. Maxwell, ${ }^{i \theta}$ it was alleged that the major shareholder had missapplied company assets. Since he could block any resolution that the company take action, the court did not follow the rule in Foss v. Harbottle and allowed the minority to take action in the company name. The cases where the courts have applied the qualifications are useful illustrations of their approach to minority rights. ${ }^{80}$

(ii) in cases of fraud or deceit.

(iii) in cases of ultra vires decisions where the court will allow the minority to take action.

(The reason for the latter two qualifications is that no resolution has in fact been passed-in the one case because if the majority has spoken

76 Id. at 378 .

70 Ante, n. 44.

78 Thte, rule has been approved in numerous Canadian cases-e.g.

8 The rule has been approved in numerous Canadian cases-e.g.

Watt v. Commonwealth Petroleum Ltd. [1938] 3 W.W.R. 696 (S.C. Alta.);

Sass V. St. Nicholas, etc. Association, [1937] S.C.R. 415.

79 (1964), 44 D.L.R. (2d) 764 (S.C. B.C.). 4 D.X.R. 714 (S.C. Alta.), where the Court did not apply the rule because an action to allot further shares might be oppressive. 
it is as a result of deceit, in the other because what they purport to do is a nullity.)

\section{(g) Curbs on Directors}

Limitations, in addition to limitations on voting rights, have been imposed either by the Act or by operation of law, which serve to protect the minority. Directors are generally the representatives of the majority. The curbs on their powers are thus an indirect protection of the minority. Directors of a public company are generally prohibited from borrowing from the company (section 14). Details of loans to directors must be disclosed in the accounts available to members (section 122 (12) ). Directors are required to declare their interest in a contract and may not, unless the articles permit, vote on the matter (section 86). But this latter restriction on voting applies only to directors' meetings, and not to a vote qua shareholders at a shareholders' meeting. ${ }^{81}$

Directors hold office in a fiduciary capacity and have a duty to advance the interests of the company as a whole. In Cook v. Deekes, the directors of a company had obtained a contract in their own names. A resolution of a general meeting (which they effectively controlled as majority shareholders) declared that the company had no interest in the contract. The Privy Council (in an appeal from Ontario) held that because of their fiduciary position, in equity, the directors' contract was in fact the property of the company. The directors had in effect been trying to make themselves a present of the company's property, and this could not be countenanced. In Piercey v. S. Mills \& Co. Ltd.., ${ }^{83}$ the directors, to prevent their removal, allotted themselves sufficient shares to give them control. This too was held to be an action inconsistent with the duties of a fiduciary.

Section 14 of the Act prohibits loans to shareholders generally in Alberta public companies. The same section also prohibits financial assistance in any other form, where it is given to enable shares of the company to be purchased. This provision, which applies to public companies only, was taken over from the United Kingdom Companies Act. ${ }^{84}$ Outsiders had been buying into companies with large resources using the company assets to finance the share acquisition. Once in control they would then divert the assets to themselves, to the prejudice of the minority. It was to prevent this evil that the section was enacted. ${ }^{85}$

\section{(h) Statutory Provisions}

Shareholders can apply to Court for a winding-up order where they feel that they are being oppressively treated. The order can be granted where it is "fair and equitable".86 This section, also adopted from United Kingdom legislation, was considered by the Cohen Commission, which indicated that the power, intended to protect a minority can be abused by the majority. ${ }^{87}$ As a result, an alternative was suggested-section 210 of the United Kingdom Act ${ }^{88}$-which allows a court in cases of oppres-

81 Central Gas Case, ante, n. 9 at 523.

82 Ante, 65

83 [1920] 1 Ch. 77. See also cases summarised by E. M. Bredin in (1964), 3 Alta. L. Rev. 333.

8419 \& 20 Geo. 5, c. $23,8.45$

$85 \mathrm{Re}$ V.G.M. Holdings, [1942] Ch. 235 (C.A.).

86 Section $179(\mathrm{e})$.

87 See ante, n. 12.
8811 \& 12 Geo. 6, c. 38. 
sion to make such order as it sees fit, to regulate the future conduct of the company, or for the purchase of the minority interest.

The Alberta Act assists dissentients by allowing the court to order a purchase of their shares where: (i) there is an objection to the enlargement of the company objects, ${ }^{80}$ or (ii) where members of a company in liquidation object to a sale of assets in exchange for an interest in the transferee company. ${ }^{90}$

In so far as a failure to give information prejudices the minority, section 122 assists them by detailing the accounts to be made available to shareholders at the annual general meeting. The remarks of Maugham, $\mathrm{J}$. should be borne in mind in assessing the value of the provision. "It is manifest that from modern balance sheets very little real information can be obtained as to the capital value of assets."11 Details of directors' loans and emoluments are to be set out, and the accounts made available to shareholders seven days before the meeting.

Section 141 allows the Lieutenant Governor, on the application of members owning one-tenth of the capital, to have the company investigated. The inspectors chosen by him can compel the officers to furnish information. Their report is then available to the applicants. Other than furnishing information, the proceedings are somewhat ineffectual, for the only effect the report has is that, "it is admissible in any legal proceedings as evidence of the opinion of the inspectors in relation to any matter contained in the report."92

Section 126 permits members holding one-tenth of the issued capital to requisition a meeting of the company, and in so far as it gives them a chance to voice their complaints, is a protection for the minority.

\section{CONCLUSION}

It is doubtful whether the Alberta Act provides the protection that the minority should have. The desire of the majority for unfettered control has resulted in a protean variety of devices. A power similar to that embodied in section 210 of the United Kingdom Act, ${ }^{, 3}$ would probably be the most effective method of affording minority protection, rather than a piece meal attack on known abuses.

89 section $44(5)$.

91 (1933), 150 L.T. 374, 375 (Ch.). Cited in Fogler v. Norcan Oils, ante, n. 29.

02 section 113

03 See ante, n. 88. A similar section appears in the British Columbia Act [1960 c. $67 \mathrm{s.} 185]$.

Its effect was considered recently in re British Columbia Electric Co. Ltd. [1965] D.L.R. 754 . 